Revista Brasileira de Farmacognosia Brazilian Journal of Pharmacognosy 21(2): 216-228, Mar./Apr. 2011

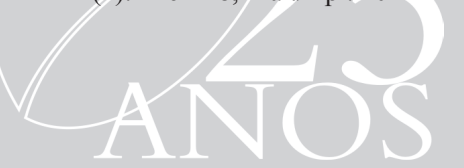

Article

Received 3 Jan 2011

Accepted 18 Jan 2011

Available online 13 May 2011

Keywords:

Dictyotaceae

secondary metabolites

terpenes

biogeography

bioactivities

ISSN 0102-695X

doi: $10.1590 / \mathrm{S} 0102-695 \mathrm{X} 2011005000079$

\section{What are and where are the bioactive terpenoids metabolites from Dictyotaceae (Phaeophyceae)}

\author{
Joel Campos De Paula, ${ }^{* 1}$ Magui A. Vallim, ${ }^{2}$ Valéria Laneuville \\ Teixeira ${ }^{2}$
}

${ }^{1}$ Programa de Pós-graduação em Biodiversidade Neotropical, Instituto de Biociencias, Universidade Federal do Estado do Rio de Janeiro, Brazil, ${ }^{2}$ Programa de Pós-graduação em Biologia Marinha, Instituto de Biologia, Universidade Federal Fluminense, Brazil.

\begin{abstract}
Dictyotaceae are a rich source of secondary metabolites, especially terpenes. These natural products have been studied for their bioactivity for human and for their ecological role in nature. The present work highlights de diversity of the Dictyotaceae terpenes, emphasizing their bioactivities and the biogeography of their sources. The sesquiterpenes are found in Padina, Dictyopteris and Taonia. Although Dictyopteris and Padina can be found in all oceans, Taonia has a more restricted distribution. Diterpenes of mixed origin have been reported in Lobophora, Taonia and Stypopodium. Stypopodium is a typically tropical and warm temperate genus. Diterpenes with the spatane and seco-spatanes skeletons are known from Spatoglossum, Stoechospermum and Rugulopteryx. Spatoglossum is distributed over all the tropical marine world. Stoechospermum is known to occur in the Indian Ocean and Rugulopteryx is distributed mainly in Asia and on the Pacific Coast of Australia. The genus Dictyota contains diterpenes as the major metabolite and are present in all oceans, reaching even the cold temperate regions of northern and southern hemispheres. The terpenoids from Dictyotaceae exhibit bioactivities such as inhibition of herbivores and antifungal, cytotoxic, antibiotic, anti-inflammatory, insecticidal and antiviral activities.
\end{abstract}

\section{Introduction}

Many marine organisms are able to produce substances derived from secondary metabolism. These metabolites, also called natural products, are present from bacteria and algae to echinoderms, mollusks, tunicates and vertebrates, through the sponges and corals (Blunt et al., 2010).

The knowledge of metabolites has helped to characterize the algae at different hierarchical levels (divisions, classes etc.) down to species (De Paula et al., 2007), and has importance for phytochemical, phylogenetic and ecological studies (Teixeira et al., 1991). Moreover, these substances have a high biotechnological potential, as evidenced by their use in the food and pharmaceutical industris that generates billions of dollars (Smit, 2004).

Technological advances in disease diagnosis, combined with democratization of access to this technology, are reflected in the increase in the number of people diagnosed with diseases caused by biological agents. In response to this scenario, the search for substances that can counteract the presence and multiplication of infection by the biological pathogens has increased. In this context, studies of natural metabolites have been shown to be a good alternative, with a diversity of sources, chemical structures and applicability. The oceans, which cover $70 \%$ of the biosphere, are also the cradle of life on Earth. Due to the longer existence of life in the marine environment, it harbors the largest Phyletic diversity of the planet. The brown algae (Phaeophyceae) are a class of almost exclusively marine organisms that have been explored for the bioactivity potential of its metabolic products, especially those of the representative family Dictyotaceae. Although it is only the third in number of species within the class, this family is a rich and diverse source of natural products, which makes it the most studied with the greatest number of known metabolites. Dictytotaceae is represented by species with apical growth from a single cell or a row of cells making up the margin. The macromorphology of these species includes flabeliform to ribbonlike plants. Micromorphologically, all have reproductive elements 
with only one plumose flagellum, while the other Phaeophyceae possess a pair of flagella. The chemistry of Dictyotaceae natural products include a rich production of terpenoids molecules of different origins and are therefore important in studies of metabolites of marine origin.

Two biogenic pathways have been described for the terpenoid formation, the mevalonate pathway and the mevalonate-independent pathway via deoxyxylulose phosphate (Dewick, 2002). Terpenoids are composed of five carbon subunits (an isoprenoid) disposed in a configuration called head and tail and are classified according to the number of isoprenoid units incorporated. In Dictyotaceae and in particular in this paper, the most bioactive products have three or four isoprenoid units, corresponding to the sesquiterpenes and diterpenes, respectively. These two classes of terpenoids can have many different structures and variants, including the addition of halogen atoms (the most common being chlorine or bromine) or fragments from other biogenic pathways. In this latter case, they are called terpenes of mixed origin, an example being the incorporation of a phloroglucinol unit into a diterpene.

As a natural source, the terpenes are strongly influenced by population distributions. For example, Freitas et al., (2007) and Vallim et al. (2007) found differences in the diterpene expression by Dictyota mertensii in different distant beaches and Ali \& Pervez (2003a, 2003b) and Ali et al. (2003; 2004) described highly oxidized diterpenes from a seco-dolastane and related dolastane producing Canistrocarpus population from the Karachi coast of the Arabian Sea.

The present work is a bried description of terpenoid diversity in Dictyotaceae and their bioactivity, algae source and distribution in the oceans. These results were presented at the II Workshop on New Bioactivies from Macroalgae.

\section{Materials and Methods}

The Dictyotaceae bioactivities were taken from the original papers and/or the annual review series Marine Natural Products, published by Natural Product Reports and covering the literature from 1977 (Faulkner, 1984) to 2009 (Blunt et al., 2011). Only bioactivities for which the active substance was described were selected. No information was used from studies limited to extracts or enriched fractions. The scientific names of the Dictyotaceae and their geographical distribution were based on information from the site algaebase (Guiry \& Guiry, 2011).

\section{Results}

Halogenated sesquiterpenes (whose main sources are the red algae) are reported in Padina antillarum (Parameswaran et al., 1994, 1996) and Dictyopteris divaricata (Ji et al., 2009), and sesquiterpenes without halogens in Dictyopteris divaricata (Song et al., 2005, 2006; Qiao et al., 2009; Wen et al., 2009), D. undulata (Song et al., 2004a) and Taonia atomaria (De Rosa et al., 1994). For the latter two genera, 36 and six species are recognized, respectively, while for Padina 37 species are still valid. The sesquiterpenes in which a phloroglucinol unit is added were reported in Dictyopteris undulata (Ochi et al., 1979a; 1979b; Cortés et al., 2001; Dave et al., 1984) and Dictyopteris divaricata (Song et al., 2004b). Alhough Dictyopteris and Padina can be found in all oceans with predominant occurrence in tropical areas, Taonia is more restricted to the North Atlantic Ocean, Caribbean, Mediterranean, South Australia and Pakistan (Figure 1). The sesquiterpenes of these genera are known to exhibit activity as an inhibitor of herbivores and antifungal, cytotoxic, antibiotic and ichthyotoxic activities. Table 1 illustrates some of the products and their activities.

Meroditerpenes, i.e., polycyclic diterpenes of mixed biogenesis characterized by a methyl hydroquinone nucleus linked to a diterpenic chain, have been reported in Lobophora papenfussii (Gerwick \& Fenical, 1982), Taonia atomaria (Ishitsuka et al., 1990), Stypopodium zonale (Gerwick \& Fenical, 1981), S. flabelliforme (Gerwick et al., 1979) and S. schimperii (Sampli et al., 2000). These metabolites can be linear, similar to those found in Fucales (Ishitsuka et al., 1979; Kusumi et al., 1979; Amico et al., 1982a,b;, Banaigs et al. 1982; 1983), or have polycyclic skeletons similar to each other, which may reveal a phylogenetic similarity between Stypopodium and Taonia. Meroditerpene compounds were reported in Stypopodium flabelliforme (Areche et al., 2009). This is a typically tropical and warm temperate genus (Figure 2) with six currently accepted species, including S. flabelliforme, $S$. schimperii and $S$. zonale that have been studied chemically. The meroditerpenes of these genera are known to exhibit cytotoxic, anti-inflammatory, insecticidal, and antivira activities. Table 2 illustrates some of the activities of meroditerpenes.

Besides the above mentioned skeletal types, Dictyotaceae are the second richest source of cyclic terpenes from marine algae, after the genus Laurencia (Rhodophyta). More than 300 diterpenoids have been reported, distributed in six genera. Diterpenes of the spatane and seco-spatane types are known from Spatoglossum (S. schmittii and S. howleii), Stoechospermum polypodioides and Rugulopteryx. While the first two genera exhibit growth via a small group of apical cells, Rugulopteryx grows by a single apical cell (De Clerck et al., 2006). Spatoglossum has 
twenty known species of which only the diterpenoid content of S. howlleii and S. schmittii have been reported (Gerwick \& Fenical, 1983; Gerwick et al., 1983). This genus is distributed over the entire tropical marine world, also reaching some warm temperate regions. Stoechospermum polypodioides is the only species of the genus known in the Indian Ocean. Rugulopteryx, with its four species, is distributed mainly in Asia and
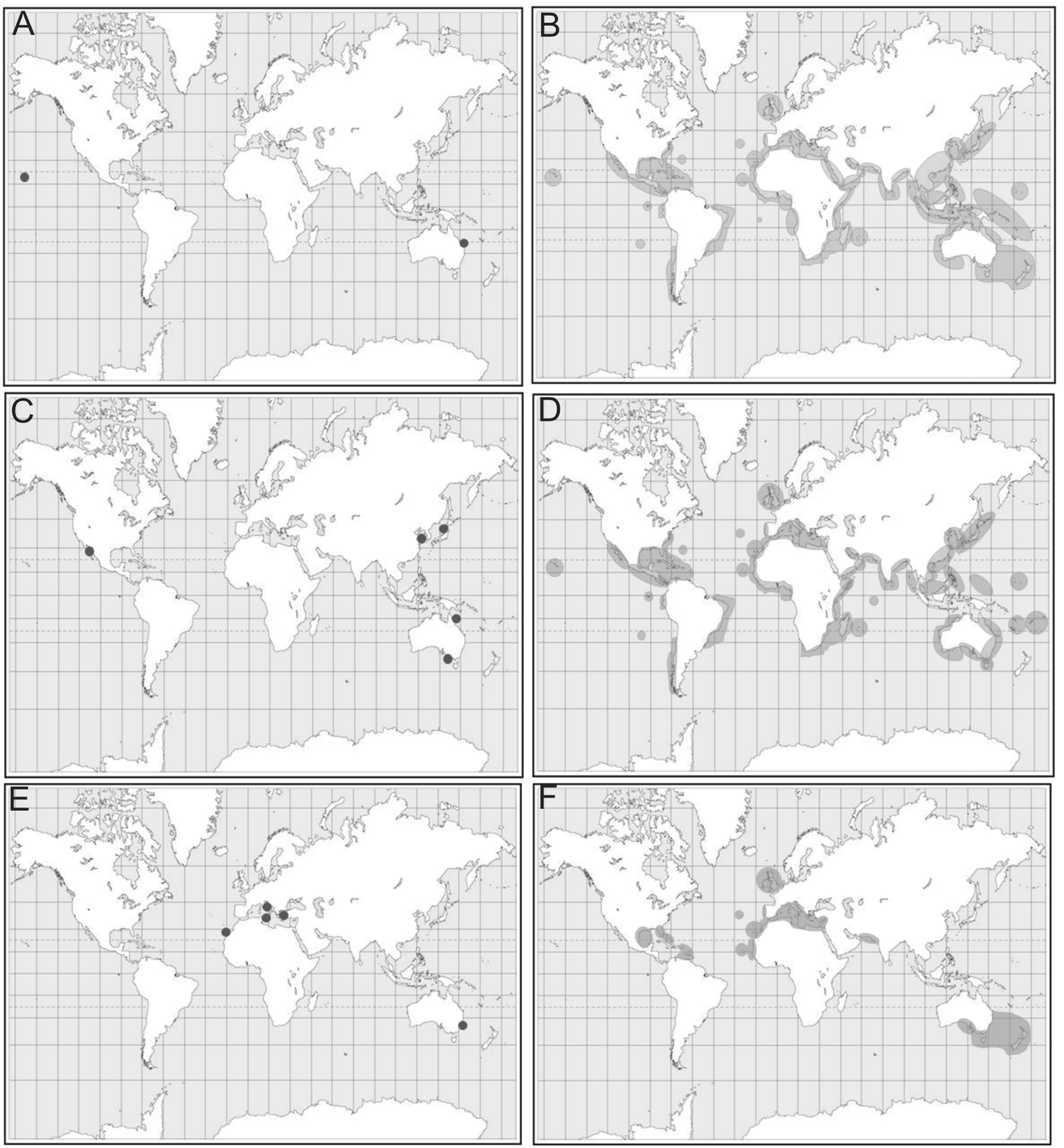

Figure 1. Places where the genera were studied chemically: Padina (A),Dictyopteris (C) e Taonia (E) and the known distribution of the genera Padina (B), Dictyopteris (D) e Taonia (F).

the Pacific Coast of Australia and, in a few instances, in the Mexican Pacific, Indian, Atlantic and eastern Mediterranean (Figure 3). These diterpenes exhibit great structural similarity, even from different genera. and there are reports of antiherbivory, antibiotic, cytotoxic, cell division inhibition and HSV antiviral activities. Table 3 shows some spatanes and related products and their bioactivities.

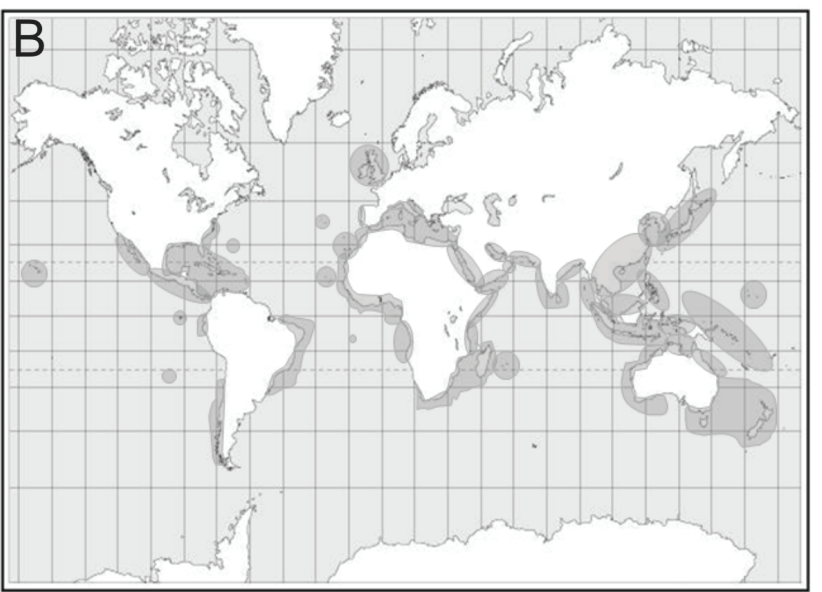


Table 1. Bioactive sesquiterpenes.

\begin{tabular}{|c|c|c|c|}
\hline Source & Activity & Product & Reference \\
\hline Dictyopteris undulata & antiherbivory & & Kurata et al., 1996 \\
\hline Dictyopteris zonaroides & antifungal & & Fenical et al., 1973 \\
\hline Dictyopteris zonaroides & citotoxic/antitumoral & & Fenical et al., 1973 \\
\hline Dictyopteris undulata & antibiotic & & Ochi et al., 1979a \\
\hline Dictyopteris undulata & ichthyotoxic & & Dave et al., 1984 \\
\hline
\end{tabular}
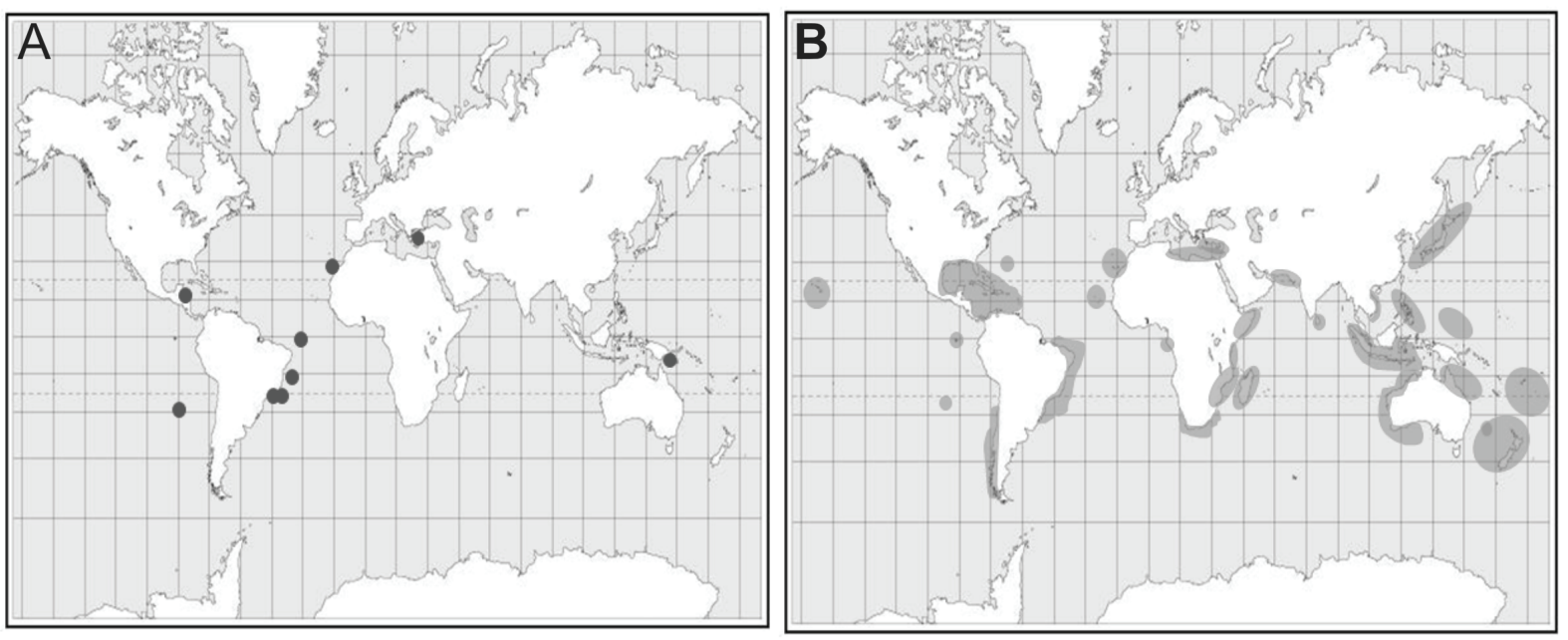

Figure 2. Places where Stypopodium was studied chemically (A) and the known distribution of the genus (B). 
Table 2. Bioactive meroditerpenes.

\begin{tabular}{|c|c|c|c|}
\hline Source & Activity & Product & Reference \\
\hline Taonia atomaria & cytotoxic/antitumoral & & Abatis et al., 2005 \\
\hline Taonia atomaria & anti-inflammatory & & Tziveleka et al., 2005 \\
\hline Taonia atomaria & radical-scavenging activity & & Nahas et al., 2007 \\
\hline Stypopodium flabelliforme & $\begin{array}{l}\text { sodium channel blocking } \\
\text { activity }\end{array}$ & & Sabry et al., 2005 \\
\hline Stypopodium flabelliforme & insecticidal & & Rovirosa et al., 1992 \\
\hline Stypopodium zonale & ichthyotoxic & & $\begin{array}{c}\text { Gerwick and Fenical, } \\
1981\end{array}$ \\
\hline Stypopodium zonale & $\begin{array}{l}\text { inhibition of } \\
\text { polymerization of } \\
\text { microtubules }\end{array}$ & & Jacobs et al., 1985 \\
\hline Stypopodium zonale & tyrosine kinase inhibitor & & Wessels et al., 1999 \\
\hline Stypopodium zonale & antiviral & & Soares et al., 2007 \\
\hline
\end{tabular}

The genus Dictyota has two distinct species groups: (1) one in which the major diterpenes have prenylated guaiane skeletons associated with xenianes, crenulidanes or dichotomanes, with other related skeletons present in lower abundance; and (2) another in which the major products are dolabellanes and related dolastanes with other related skeletons in lower abundance. There is no co-occurrence of these two different kinds of major products or of those with smaller abundance in the same species. When this cooccurrance is reported in the literature, it is attributed to the presence of a mixture of species. Awad et al. (2008) recorded the presence of xeniane in Padina pavonica. Prenylated guaiane species are distributed mainly in the tropics, but are present in all oceans, even reaching the cold temperate regions of the northern and southern 
hemispheres (Figure 4). Among the biological activities described are anti-retroviral, cytotoxic, antibiotic, and anti-herbivory activities. Table 4 illustrates prenylated guaiane and related products and their bioactivities.
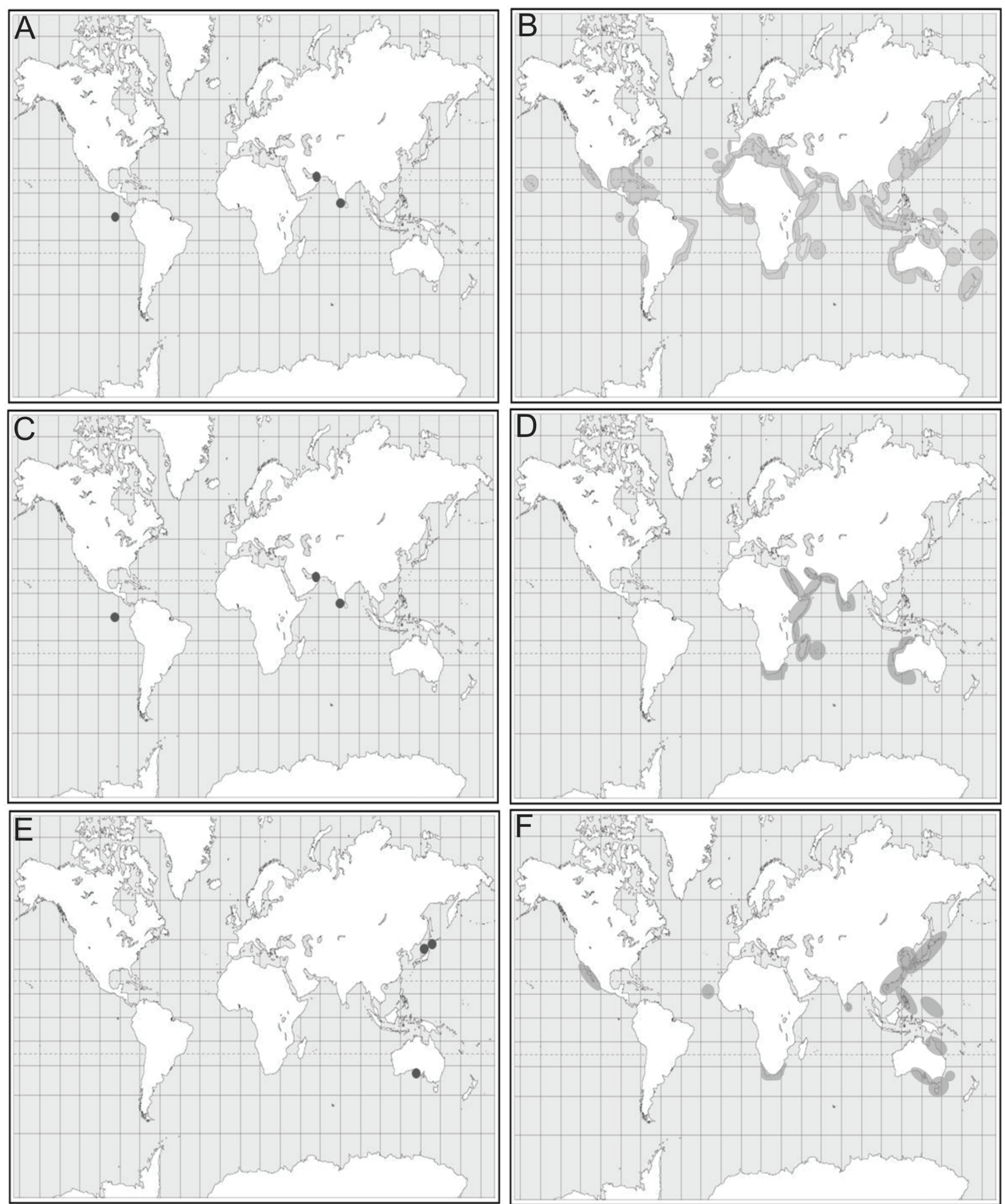

Figure 3. Places where the spatane producing genera were studied chemically: Spatoglossum (A), Stoechospermum (C) and Rugulopteryx (E) and the known distribution of the genera Spatoglossum (B), Stoechospermum (D) and Rugulopteryx (F). 
Table 3. Bioactivity of spatane and related metabolites.

\begin{tabular}{ccc}
\hline Source & Activity \\
Spatoglossum schmittii & inhibitor of cell division \\
Spatoglossum schmittii & Cytotoxic/antitumoral \\
Stoechospermum \\
polypodioides
\end{tabular}
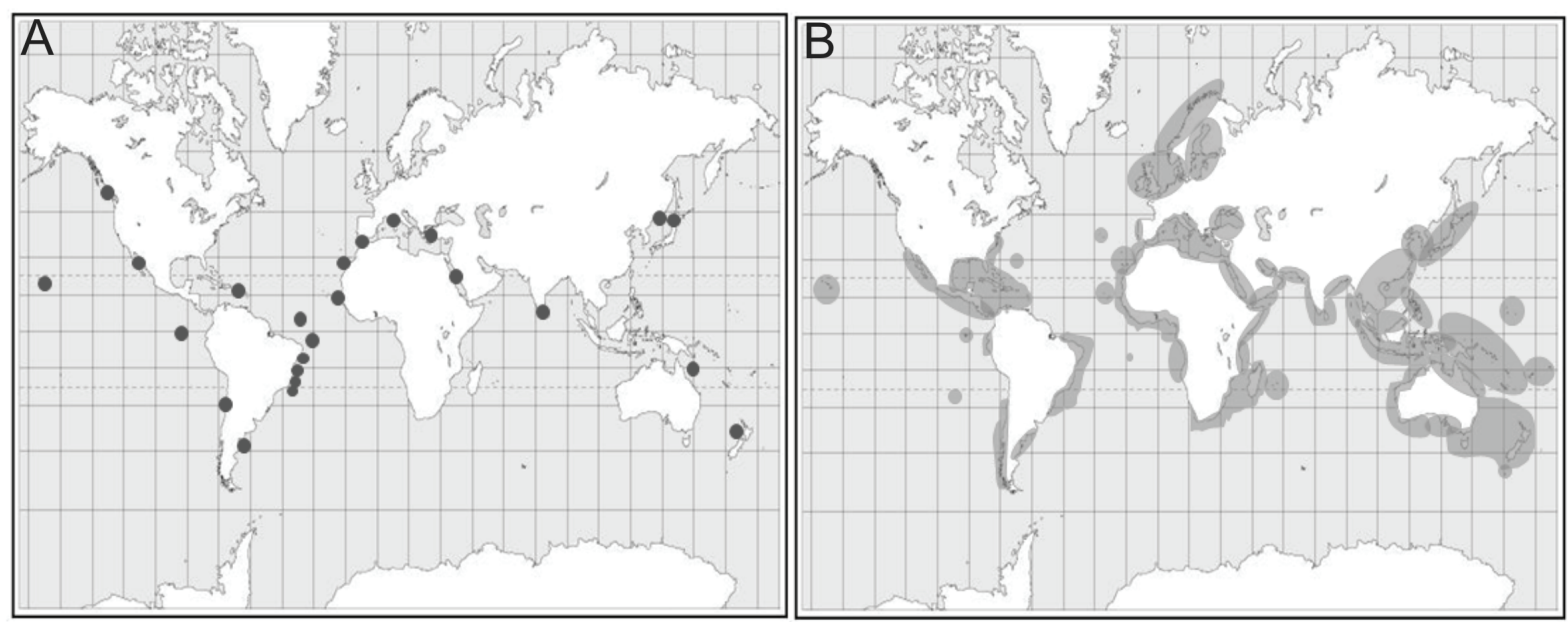

Figure 4. Places where prenylated guaiane species were studied chemically (A) and the known distribution of the genus Dictyota (B).

The Dictyota species that produce dolabellanes have a geographical distribution that is somewhat more restricted to tropical regions, extending to the subtropics compared to their prenylated guaiane counterparts (Figure 5). Natural products of these species are reported to have antiviral, chemical defense, bactericidal and ichthyotoxic activities. Table 5 illustrates dolabellanes and their bioactivities.

The Dictyota species that produce secodolastanes and dolastanes were transferred by De
Clerck et al. (2006) to the genus Canistrocarpus. Although these species also produce dolastanes, these products have chemical characteristics that distinguish them from those of Dictyota origin. The bioactivities of this genus include antiviral, anti-herbivory and enzyme inhibitor activities. Canistrocarpus has three species, distributed mainly in the tropical regions of all oceans and extending to warm temperate regions (Figure 6). Table 6 illustrates seco-dolastanes and related dolastanes and their bioactivities. Discussion 
Table 4: Bioactivity of prenylated guaianes and related metabolites.

\begin{tabular}{|c|c|c|c|}
\hline Source & Activity & Product & Reference \\
\hline Dictyota dichotoma & citotoxic/antitumoral & & Durán et al., 1997 \\
\hline Dictyota coriacea & antibiotic activity & & Hirschfeld et al., 1973 \\
\hline Dictyota ligulata & citotoxic/antitumoral & & Bouaicha et al., 1993 \\
\hline Dictyota ligulata & antibacterial activity & & Tringali et al., 1988 \\
\hline Dictyota menstrualis & antiviral & & Pereira et al., 2004 \\
\hline
\end{tabular}
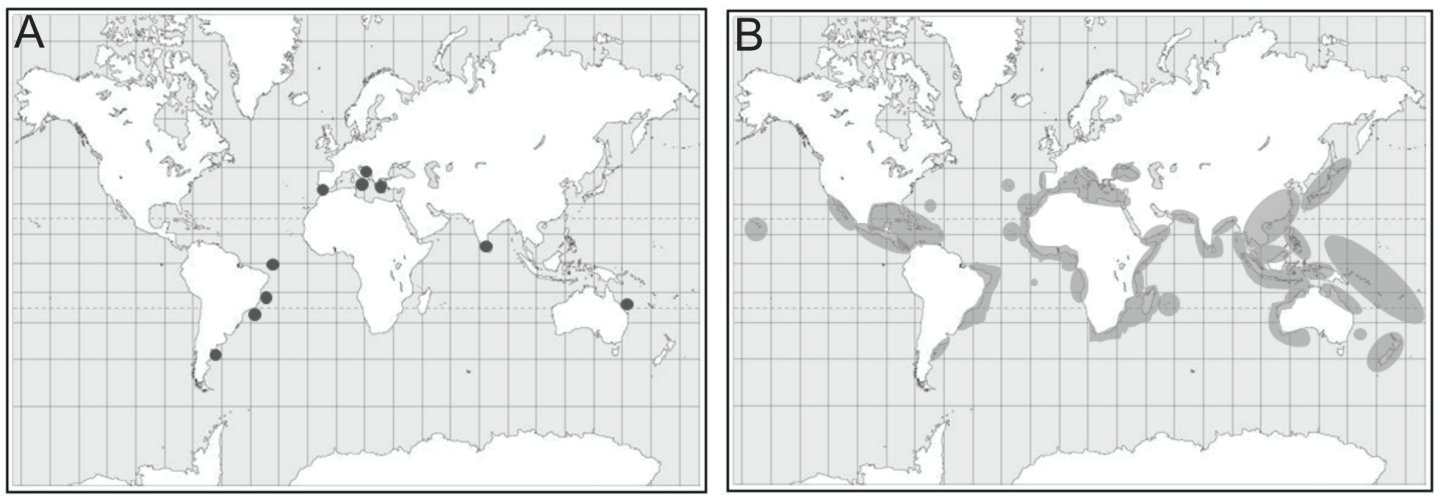

Figure 5. Places where dolabellane producing species were studied chemically (A) and the known distribution of the Dictyota dolabellanes producing species (B).
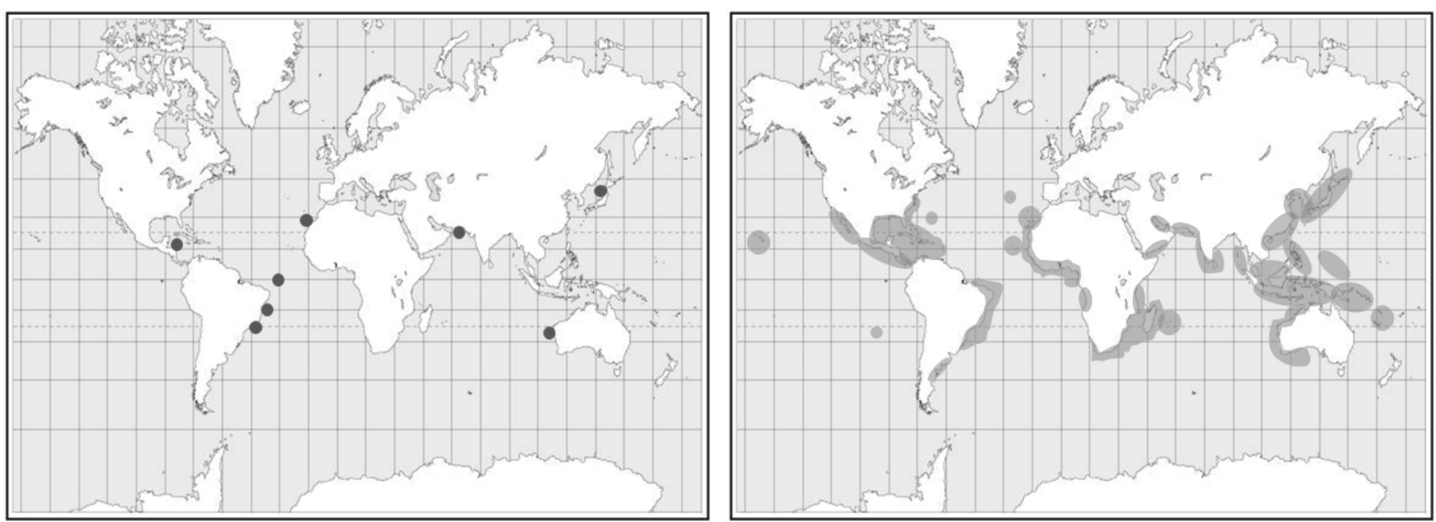

Figure 6. Places where seco-dolastanes were studied chemically (A) and the known distribution of the genus Canistrocarpus (B). 
Table 5. Dolabellane bioactivity

\begin{tabular}{|c|c|c|c|}
\hline Source & Activity & Product & Reference \\
\hline Dictyota fasciola & ichthyotoxic & & De Rosa et al., 1984 \\
\hline Dictyota friabilis & antiherbivory activity & & Barbosa et al., 2004b \\
\hline Dictyota friabilis & antiviral & & Barbosa et al., 2004a \\
\hline
\end{tabular}

Table 6. Bioactivity of seco-dolastanes and related dolastanes.

$\begin{array}{lll}\text { Source } & \text { Activity } & \text { RTPase inhibitory } \\ \text { Canistrocarpus cervicornis } & \text { Garcia et al., 2009 } \\ \text { Canistrocarpus cervicornis } & \text { anti-herbivory }\end{array}$

The Dictyotaceae are a rich source of bioactive terpenes (Vallim et al., 2010). Feedingdeterrence activity could be found for the sesquiterpenes in Dictyopteris (Kurata et al., 1996), for spatanes in Rugulopteryx (Kurata et al., 1988; 1989), for prenylated guaianes and dolabellanes in Dictyota (Hardt et al., 1996; Barbosa et al., 2004b) and for secodolastanes in Canistrocarpus (De Paula et al., 2001). Several of these compounds found in Dictyotaceae exhibit a broad spectrum of feeding deterrence against herbivores (Pereira et al., 2000a; 2000b), including mollusks, fishes, sea urchins, amphipods and crabs. The biogeographical distribution of secondary metabolites from
Dictyotaceae could be the result of different evolutionary herbivore pressures (Pereira et al., 2000a; Vallim et al., 2005).

Cytotoxic activities were evaluated in several human tumor cell lines for sesquiterpenes from Dictyopteris (Fenical et al., 1973), for meroditerpenes from Stypopodium and Taonia (Dorta et al., 2002; Abatis et al., 2005) as well as for prenylated guaianes and dolabellane diterpenes from Dictyota (Durán et al., 1997; Tringali et al., 1984), and for spatanes from Spatoglossum (Gerwick \& Fenical, 1983). Taonia and the diterpene producing species of Spatoglossum have restricted distributions. Hence, the places where they occur 
must be adequately protected in order to preserve them for future research.

Antifungal activity was found only for sesquiterpenes from Dictyopteris. The terpene from another Phaeophyceae, Lobophora variegata, did not exhibit this activity (Kubanek et al., 2003).

Compounds with anti-inflammatory activity were found in Taonia (Tziveleka et al., 2005) and inhibition of microtubules (Jacobs et al., 1985) and enzymes (Wessels et al., 1999) was exhibited by meroditerpenes from Stypopodium. This last activity was also shown by Canistrocarpus dolastanes (Garcia et al., 2009).

Antiviral activity, in particular that against HIV and HSV, was exhibited by several Meroditerpenes from Stypopodium (Soares et al., 2007), by dichotomane (Pereira et al., 2004), and by dolabellane (Barbosa et al., 2004a). Although not from a Dictyotaceae, a halogenated sesquiterpene from the red alga Peyssonelia also exhibit antiviral activity (Loya et al., 1995). Because Padina (Parameswaran et al., 1994; 1996) and Dictyopteris (Ji et al., 2009) also contain halogenated sesquiterpenes, these algae could become a source of antiviral molecules.

Comparing the places in the world where these algae have been chemically studied with those where the presence of terpenoids is known and with the species distribution, it is easy to recognize that bioactivies of metabolites from Dictyotaceae have a vast potential, given the changes that might occur in gene expression in local populations. In this context, greater attention to preservation of coastal areas is necessary in places where human pressures have increased and where seaweeds and their metabolites are found, given their importance for marine ecology and human health.

\section{Acknowledgment}

fellowship.

VLT is grateful to the CNPq for a productivity

\section{References}

Abatis D, Vagias C, Galanakis D, Norris JN, Moreau D, Roussakis C, Roussis V 2005. Atomarianones $\mathrm{A}$ and B: two cytotoxic meroditerpenes from the brown alga Taonia atomaria. Tetrahedron Lett 46: 8525-8529.

Ali MS, Pervez MK 2003a. Seco-dolastanes from the marine brown alga Dictyota dichotoma (Huds.) Lamour. ZNaturforschung 58b: 438-442.

Ali M S, Pervez MK 2003b. Ring-A hydroxylated dolastanes from the marine brown alga Dictyota dichotoma (Huds.) Lamour. Nat Prod Res 17: 281-
283.

Ali MS, Pervez MK, Saleem M, Ahmed F 2003. Dichotenone-A and -B: two new enones from the marine brown alga Dictyota dichotoma (Hudson) Lamour. Nat Prod Res 17: 301-306.

Ali M S, Pervez M K, Ahmed F, Saleem M 2004. Dichotenol-A, B and C: the C-16 oxidized secodolastanes from the marine brown alga Dictyota dichotoma (Huds.) Lamour. Nat Prod Res 18: 543549.

Amico V, Oriente G, Piattelli M, Ruberto G, Tringali C 1982a. 2 novel phenolic-compounds from the brown alga Cystoseira caespitosa. J Chem Res 9: 262-263.

Amico V, Oriente G, Piattelli M, Ruberto G, Tringali C 1982b. A quinone-hydroquinone couple from the Brown alga Cystoseira stricta. Phytochemistry 21: 421-424.

Areche C, San-Martín A, Rovirosa J, Soto-Delgado J, Contreras R 2009. An unusual halogenated meroditerpenoid from Stypopodium flabelliforme: Studies by NMR spectroscopic and computational methods. Phytochemistry 70: 1315-1320.

Awad NE, Selim MA, Metawe HM, Matloub AA 2008. Cytotoxic xenicane diterpenes from the brown alga Padina pavonia (L.) Gaill. Phytother Res 22: 1610-1613.

Banaigs B, Francisco C, Gonzalez E, Codomier L, Fenical W 1982. Hydroxylated diterpenoid-hydroquinones from cystoseira elegans: significant products or artifacts? Tetrahedron Lett 23: 3271-3272.

Banaigs B, Francisco C, Gonzalez E, Fenical W 1983. Diterpenoid metabolites from the marine alga Cystoseira elegans. Tetrahedron 39: 629-638.

Barbosa JP, Pereira, RC, Abrantes JL, Cirne-Santos CC, Rebello MA, Frugulhetti ICPP, Teixeira, VL 2004a. In vitro antiviral diterpenes from Brazilian brown alga Dictyota pfaffii. Planta Med 70: 856-860.

Barbosa JP, Teixeira, VL, Pereira, RC 2004b. A dolabellane diterpene from the brown alga Dictyota pfaffii as chemical defense against herbivores. Bot Mar 47: 147-151.

Blunt JW, Copp BR, Munro MHG, Northcotec PT, Prinsep MR 2010. Marine natural products. Nat Prod Rep 27: 165-237.

Blunt JW, Copp BR, Munro Murray HG, Northcotec PT, Prinsep MR 2011. Marine natural products. Nat Prod Rep 28: on line published.

Bouaicha N, Pesando D, Puel D, Tringali C 1993. Cytotoxic diterpenoids from the brown alga Dilophus ligulatus. J Nat Prod 56: 1747-1752.

Cortés M, Valderrama JA, Cuellar M, Armstrong V, Preite M 2001. Synthesis of (+)-cyclozonarone and the absolute configuration of naturally occurring (-)-cyclozonarone. J Nat Prod 64: 348-349. 
Dave M-N, Kusumi T, Ishitsuka M, Iwashita T, Kakisawa H 1984. A piscicidal chromanol and a chromenol from the brown alga Dictyopteris undulata. Heterocycles 22: 2301-2307.

De Clerck O, Leliaert F, Verbruggen H, Lane CE, De Paula JC, Payo DA, Coppejans E 2006. A revised classification of the dictyoteae (Dictyotales, Phaeophyceae) based on rbcL and 26S ribosomal DNA sequence analyses. J Phycol 42: 1271-1288.

De Paula JC, Pedrini AG, Pinheiro MD, Pereira RC, Teixeira VL 2001. Chemical similarity between the brown algae Dictyota cervicornis and D. pardalis (Dictyotales, Phaeophyta). Biochem Syst Ecol 29: 425-427.

De Paula JC, Bueno LB, Frugulhetti ICPP, YoneshigueValentin Y, Teixeira VL 2007. Dictyota dolabellana sp. nov. (Dictyotaceae, Phaeophyceae) based on morphological and chemical data. Bot Mar 50: 288-293.

De Rosa S, De Giulio A, Iodice C, Zavodink N 1994. Sesquiterpenes from the brown alga Taonia atomaria. Phytochemistry 37: 1327-1330.

De Rosa S, De Stefano S, Macura S, Trivellone E, Zavodnik N 1984. Chemical studies of north adriatic seaweeds-I. New dolabellane diterpenes from the brown alga Dilophus fasciola. Tetrahedron 40: 4991-4995.

De Silva SSM, Gamage SKT, Kumar NS, Balasubramaniam S 1982. Anti-bacterial activity of extracts from the Brown seaweed stoechospermum marginatum. Phytochemistry 21: 944-945.

Dewick PM 2002. The biosynthesis of C5-C25 terpenoid compounds. Nat Prod Rep 19: 181-222.

Dorta E, Cueto M, Bito I, Darias J 2002. New terpenoids from the brown alga Stypopodium zonale. J Nat Prod 65: 1727-1730.

Durán R, Zubía E, Ortega MJ, Salvá J 1997. New diterpenoids from the alga Dictyota dichotoma. Tetrahedron 53: 8675-8688.

Faulkner JD 1984. Marine natural products: metabolites of marine algae and herbivorous marine molluscs. Nat Prod Rep 1: 251-280.

Fenical W, Sims JJ, Squatrito D, Wing RM, Radlick P 1973. Zonarol and isozonarol, fungitoxic hydroquinones from the brown seaweed Dictyopteris zonarioides. J Org Chem 38: 2383-2386.

Freitas OSP, Oliveira AS, De Paula JC, Pereira, RC, Cavalcanti DN, Teixeira, VL 2007. Chemical variation in the diterpenes from the Brazilian brown alga Dictyota mertensii (Dictyotaceae, Phaeophyta). Nat Prod Commun 2: 13-15.

Garcia DG, Bianco EM, Santos MCB, Pereira RC, Faria MVC, Teixeira VL, Burth P 2009. Inhibition of mammal $\mathrm{Na}+\mathrm{K}+$-ATPase by diterpenes extracted from the Brazilian brown alga Dictyota cervicornis.
Phytother Res 23: 943-947.

Gerwick WH, Fenical W, Fritsch N, Clardy J 1979. Stypotriol and stypoldione - ichthyotoxins of mixed biogenesis from the marine alga Stypopodium zonale. Tetrahedron Lett 2: 145-148.

Gerwick WH, Fenical W 1981. Ichthyotoxic and cytotoxic metabolites of the tropical brown alga Stypopodium zonale (Lamouroux) Papenfuss. J Org Chem 46: 22-27.

Gerwick WH, Fenical W 1982. Phenolic lipids from related marine algae of the order Dictyotales. Phytochemistry 21: 633-637.

Gerwick WH, Fenical W 1983. Spatane diterpenoids from the tropical marine algae Spatoglossum schmittii and Spatoglossum howleii (Dictyotaceae). J Org Chem 48: 3325-3329.

Gerwick WH, Fenical W, Engen DV, Clardy J 1983. Isolation and structure of spatol, a potent inhibitor of cell replication from the brown seaweed Spatoglossum schmittii. J Am Chem Soc 102: 7991-7993.

Guiry, MD, Guiry GM 2011. Algae Base. World-wide electronic publication, National University of Ireland, Galway. http://www.algaebase.org.

Hardt IH, Fenical W, Cronin G, Hay ME 1996. Acutilols, potent herbivore feeding deterrents from the tropical brown alga, Dictyota acutiloba. Phytochemistry 43: 71-73.

Hirschfeld DR, Fenical W, Lin GHY, Wing RM, Radlick P, Sims JJ 1973. Marine natural products. VIII. Pachydictyol A, an exceptional diterpene alcohol from the brown alga, Pachydictyon coriaceum. $J$ Am Chem Soc 95: 4049-4050.

Ishitsuka M, Kusumi T, Nomura Y, Konno T, Kakisawa H 1979. New geranylgeranylbenzoquinone derivatives from Sargassum tortile. Chem Lett 10: 1269-1272.

Ishitsuka MO, Kusumi T, Ichikawa A, Kakisawa H 1990. Bicyclic diterpenes from two species of brown algae of the Dictyotaceae. Phytochemistry 29: 2605-2610.

Jacobs RS, Culver P, Langdon R, O'Brien T, White S 1985. Some pharmacological observations on marine natural products. Tetrahedron 41: 981-984.

Ji N-Y, Wen W, Li X-M, Xue Q-Z, Xiao H-L, Wang B-G 2009. Brominated selinane sesquiterpenes from the marine brown alga Dictyopteris divaricata. Mar Drugs 7: 355-360.

Kubanek J, Jensen PR, Keifer PA, Sullards MC, Collins DO, Fenical W 2003. Seaweed resistance to microbial attack: a targeted chemical defense against marine fungi. Proc Nat Acad Sci USA 100: 6916-6921.

Kurata K, Shiraishi K, Takato T, Taniguchi K, Suzuki MA 1988. New feeding-deterrent diterpenoids from brown alga Dilophus okamurae Dawson. Chem Lett 10: 1629-1632. 
Kurata K, Taniguchi K, Shiraishi K, Suzuki M 1989. Structures of secospapane-type diterpene with feeding-deterrent activity from the brown alga Dilophus okamurae. Tetrahedron Lett 30: 15671570 .

Kurata K, Taniguchi K, Suzuki M 1996. Cyclozonarone, a sesquiterpene-substituted benzoquinone derivative from the brown alga dictyopteris undulata. Phytochemistry 41: 749-752.

Kusumi T, Shibata Y, Ishitsuka M, Kinoshita T, Kakisawa H 1979. Structures of new plastoquinones from the brown alga Sargassum serratifolium. Chem Lett 3: 277-278.

Loya S, Bakhanashvili M, Kashman Y, Hizi A 1995. Peyssonols A e B, two novel inhibitors of the reverse transcriptases of human immunodeficiency virus types 1 and 2. Arch Biochem Biophys 316: 789-796.

Ochi M, Kotsuki H, Inoue S, Taniguchi M, Tokoroyama T 1979a. Isolation of 2-(3,7,11-trimethyl-2,6,10dodecatrienyl) hydroquinone from the brown seaweed Dictyopteris undulate. Chem Lett 7: 831832 .

Ochi M, Kotsuki H, Muraoka K, Tokoroyama T 1979b. Structure of yahazunol, a new sesquiterpenesubstituted hydroquinone from the brown seaweed Dictyopteris undulata Okamura. Bull Chem Soc Jpn 52: 629-630.

Parameswaran PS, Bhat KL, Das B, Kamat SY, Harnos S 1994. Halogenated terpenoids from the brown alga Padina tetrastromatica (Hauck). Indian $J$ Chem Sect B 33: 1006.

Parameswaran PS, Naik CG, Das B, Kamat SY, Bose AK, Nair MSR 1996. Constituents of the brown alga Padina tetrastromatica (Hauck). Indian $J$ Chem Sect B 35: 463-467.

Pereira RC, Cavalcanti DN, Teixeira VL 2000a. Effect of secondary metabolites from the tropical Brazilian brown alga Dictyota menstrualis on the feeding by amphipod herbivores. Mar Ecol Prog Ser 205: 95100.

Pereira RC, Donato R, Cavalcanti DN, Teixeira VL 2000 b. Chemotaxis and chemical defenses in seaweed susceptibility to herbivory. Rev Bras Biol 59: $407-$ 419.

Pereira HS, Leão-Ferreira LR, Moussatché N, Teixeira VL, Cavalcanti DN, Costa LJ, Diaz R, Frugulhetti ICPP 2004. Antiviral activity of diterpenes isolated from the Brazilian marine alga Dictyota menstrualis against human immunodeficiency virus type 1 (HIV-1). Antiviral Res 64: 69-76.

Qiao Y-Y, Ji N-Y, Wen W, Yin X-L, Xue Q-Z 2009. A new epoxy-cadinane sesquiterpene from the marine brown alga Dictyopteris divaricata. Mar Drugs 7: 600-604.
Rovirosa J, Sepúlveda M, Quezada E, San-Martín A 1992. Isoepitaondiol, a diterpenoid of Stypopodium flabelliforme and the insecticidal activity of stypotriol, epitaondiol and derivatives. Phytochemistry 31: 2679-2681.

Sabry OMM, Andrews S, McPhail KL, Goeger DE, Yokochi A, LePage KT, Murray TF, Gerwick WH 2005. neurotoxic meroditerpenoids from the tropical marine brown alga Stypopodium flabelliforme. $J$ Nat Prod 68: 1022-1030.

Sampli P, Tsitsimpikou C, Vagias C, Harvala C, Roussis V 2000. Schimperiol, a new meroterpenoid from the brown alga Stypopodium schimperi. Nat Prod Lett 14: 365-372.

Smit AJ 2004. Medicinal and pharmaceutical uses of seaweed natural products: A review. J Appl Phycol 16: 245-262.

Soares AR, Abrantes JL, Souza TML, Fontes CFL, Pereira RC, Frugulhetti ICDP, Teixeira VL 2007. In vitro antiviral effect of meroditerpenes isolated from the Brazilian seaweed Stypopodium zonale (Dictyotales). Planta Med 73: 1221-1224.

Song F, Fan X, Xu XL, Zhao JL, Yang Y, Shi JG 2004a. Cadinane sesquiterpenes from the brown alga Dictyopteris divaricata. J Nat Prod 67: 16441649.

Song FH, Fan X, Xu XL, Zhao JL, Han LJ, Shi JG 2004 b. A new sesquiterpene-substituted benzoic acid from the brown alga Dictyopteris divaricata. Chin Chem Lett 15: 316-318.

Song F, Xu X, Li S, Wang S, Zhao J, Cao P, Yang Y, Fan X, Shi J, He L, Lü Y 2005. Norsesquiterpenes from the brown alga Dictyopteris divaricata. J Nat Prod 68: 1309-1313.

Song F, Xu X, Li S, Wang S, Zhao J, Yang Y, Fan X, Shi J, He L 2006. Minor sesquiterpenes with new carbon skeletons from the brown alga Dictyopteris divaricata. J Nat Prod 69: 1261-1266.

Teixeira VL, Kelecom, A, Gottlieb OR 1991. Produtos Naturais de algas Marinhas. Quim Nova 14: 83-90.

Tringali C, Oriente G, Piattelli M, Geraci C, Nicolosi G, Breitmaier E 1988. Crenuladial, an antimicrobial diterpenoid from the brown alga Dilophus ligulatus. Can J Chem 66: 2799-2802.

Tringali C, Oriente G, Piatelli M, Nicolosi G 1984. Structure and conformation of two new dolabellanebased diterpenes from Dictyota sp. J Nat Prod 47: 615-619.

Tziveleka L-A, Abatis D, Paulus K, Bauer R, Vagias C, Roussis V 2005. Marine polyprenylated hydroquinones, quinones, and chromenols with inhibitory effects on leukotriene formation. Chem Biodivers 2: 901-909.

Vallim MA, De Paula JC, Pereira RC, Teixeira VL 2005. The diterpenes from Dictyotacean marine brown 
algae in the Tropical Atlantic American region. Biochem System Ecol 33: 1-16.

Vallim MA, Teixeira VL, Pereira RC 2007. Feedingdeterrent properties of diterpenes of Dictyota mertensii (Phaeophyceae, Dictyotales). Braz J Ocean 55: 223-229.

Vallim MA, Barbosa JE, Cavalcanti DN, De Paula JC, Silva, VAGG, Teixeira VL, Paixão ICNP 2010. In vitro antiviral activity of diterpenes isolated from the Brazilian brown alga Canistrocarpus cervicornis. J Med Plant Res 4: 2379-2382.

Wen W, Li F, Ji N-Y, Li X-M, Cui C-M, Li X-D, Zhang L-N, Xue Q-Z, Wang B-G 2009. A new cadinane sesquiterpene from the marine brown alga Dictyopteris divaricata. Molecules 14: 2273-2277.
Wessels M, König GM, Wright AD 1999. A new tyrosine kinase inhibitor from the marine brown alga Stypopodium Zonale. J Nat Prod 62: 927-930.

\section{*Correspondence}

Joel Campos De Paula

Programa de Pós-graduação em Biodiversidade Neotropical, Instituto de Biociências, Universidade Federal do Estado do Rio de Janeiro

Avenida Pasteur 458, Urca, 22.290-240 Rio de Janeiro-RJ, Brazil

depaula@unirio.br

Tel.: +552122445681 